\title{
Gallimaufry: News and events from the British Dam Society
}

Welcome to the second issue of 2015. This is the first of two special issues that consists of papers presented and discussed at the Supervising Engineers' Forum, held in Birmingham, UK, in April 2015.

This first issue includes the forum write-up, penned by one of the forum organisers, Newman Booth of Yorkshire Water (Booth, 2015). The remainder of this issue covers the presentations and briefings that updated the supervising engineers on the changes to the legislative framework and how this may impact on their role. Papers that cover the majority of the technical presentations given at the Forum are also included. The remaining papers presented at the Forum will be included within Issue 3 of Dams and Reservoirs journal.

First presented is a paper that covers the enactment of the Reservoirs (Scotland) Act 2011 (2011) given by Huw Thomas (2015). Regulatory duties in Scotland are transferring from local authorities to the Scottish Environment Protection Agency (SEPA). Huw's paper summarises the transitional timetable and the risk designation process, as well as commenting on the role of SEPA.

This paper is followed by a paper which aims to provide some guidance to supervising engineers on the changes to the Reservoirs Act (1975) in England and the impact this will have on their role and responsibilities (Warren, 2015).

A paper by Mark Acford (2015) covers the implementation of the Environment Agency risk designations. He leads the reader through the legal background to the risk designation process, summarises the approach that has been taken to the work, and outlines how challenges to risk designations can be made.

We also include in this issue a briefing note from Natural Resources Wales (NRW) on the implementation of reservoir safety legislation in Wales. This provides an update on the presentation given by Matthew O'Brien (2015) at the Forum, which summarised the differences between the English and Welsh legislation, the timescales of enactment and the future role of the supervising engineer.

The first technical paper, by Gemma Morris \& Stephen Shakespeare (2015) presents an overview of the emergency planning guidance relating to dams and reservoirs. It discusses the requirement for 'on-site' and 'off-site' emergency plans and the framework of general emergency planning legislation.

These papers are then followed by a series of case studies. The first case study is by Jonathan Howard (2015) and covers the implementation of several measures in the interests of safety, which were required on Ystradfellte dam and draw-off tower. The paper describes the challenges and solutions to allow the replacement of landings and ladders within the tower.

Louise Shaw (2015) then presents her paper on the Coedty tilting gate refurbishment and describes the work undertaken to three automatic mechanical tilting gates over the central spillway.

Finally, Tony Judge (2015) presents his paper on the future of Scottish redundant reservoirs, with a summary of an options assessment, which included a comparison between the estimated costs of the outstanding measures in the interests of safety and the cost of discontinuing the reservoirs.

The final article in this issue is a summary of the work undertaken by the Young Engineers' Forum, as presented by Samuel Tudor (2015). The Forum aspires to create an environment to assist in the development of our younger engineers and Sam's paper outlines the objectives and delivery aims of the Young Engineers' Forum.

I would like to take this opportunity to thank our contributors to the Dams and Reservoirs journal. Without interesting and informative papers, such as those presented in this issue we would not be able to successfully publish our journal, which I know we all enjoy reading. Please could I request that our readership continue to highlight topics and schemes that they think would be of interest to the wider readership and contact the editor with a proposed title or subject in the first instance. Please note that our editorial panel is on hand to provide mentoring and guidance in preparation of papers, should you require.

\section{Anthea Peters}


"Water as such" - the Great Beer Flood of 1814

On the $17^{\text {th }}$ October 1814 eight people were killed and an unknown number were injured in the Great Beer Flood of London.

The Meux \& Company Brewery was situated in the Parish of St Giles, London, on Tottenham Court Road. It was situated among poor houses and tenements of the Parish of St Giles Rookery, where whole families lived in basement rooms.

A huge vat that contained over 6100001 of beer ruptured. This caused other vats in the building to fail in a domino effect, releasing more than 14700001 of beer into the streets. The vat was 22 feet $(7 \mathrm{~m})$ tall and 60 feet $(18 \mathrm{~m})$ wide.

The resulting wave, at least 15 feet $(4.5 \mathrm{~m})$ high, destroyed two houses and brought down the walls of the nearby Tavistock Arms. Basements were filled with beer, killing the inhabitants and within minutes George Street and New Street were swamped with alcohol, killing a mother and daughter who were taking tea and overcoming a room of people gathered for a wake.

There were suggestions that these attempts were severely hampered by people trying to collect the beer for consumption but some references state that this was not the case.

The brewery was eventually taken to court but the disaster was ruled to be 'an Act of God' by the judge and jury, leaving no one responsible! The company then found it difficult to cope with the financial repercussions of the disaster, with a significant loss of sales and having already paid the duty on the beer. They applied to Parliament to reclaim the duty in order to enable them to continue trading and were successful! The brewery was demolished in 1922 and today the Dominion Theatre occupies part of the site.

So, this is clearly another example of 'water as such' being able to kill people. It is thought that the failure of one of the seven steel straps around the vat caused the failure to occur, which led to a cascade failure. Again, people were killed in basements where they could not evacuate before they were drowned as the basements filled up. This is maybe not a 'large raised reservoir', maybe not water as such, but a rapid failure, a cascade failure; the velocity and depth was sufficient to cause walls to collapse, the population at risk included people in basements, and eight people lost their lives.

Further information on the great beer flood can be found in an article by Alan Bellows (Bellows, 2015), and on the history. com website (Klein, 2014).

Steve Morris and Andy Hughes

\section{REFERENCES}

Acford M (2015) The Reservoirs Act 1975 and reservoir risk designations. Dams and Reservoirs 25(2): 56-57, http://dx.doi.org/10.1680/jdare.15.00025.

Bellows A (2015) Beer flood claims nine souls. See http://www.damninteresting.com/beer-flood-claims-ninesouls/ (accessed 01/02/2016)

Booth N (2015) The 2015 Supervising Engineers' Forum. Dams and Reservoirs 25(2): 47-50, http://dx.doi.org/ 10.1680/jdare.15.00026.

Howard J (2015) Ystradfellte dam: health and safety improvements. Dams and Reservoirs 25(2): 67-73, http://dx.doi.org/10.1680/jdare.16.00006.

Judge T (2015) Managing Scottish Water's non-operational reservoirs. Dams and Reservoirs 25(2): 79-84, http://dx.doi.org/10.1680/jdare.15.00017.

Klein C (2014) The London Beer Flood. See http://www.history. com/news/the-london-beer-flood-200-years-ago (Accessed 01/02/2016)

Morris G and Shakespeare S (2015) How prepared are we for a reservoir emergency? Dams and Reservoirs 25(2): 62-66, http://dx.doi.org/10.1680/jdare.16.00004.

O'Brien M (2015) An update on reservoir safety legislation in Wales. Dams and Reservoirs 25(2): 58-61, http://dx.doi.org/ 10.1680/jdare.15.00024.

Reservoirs Act 1975 (1975) Elizabeth II. Chapter 23. The Stationery Office, London, UK.

Reservoirs (Scotland) Act 2011 (2011) Elizabeth II. Asp 9. The Stationery Office, Edinburgh, UK.

Shaw L (2015) Coedty reservoir spillway tilting gate refurbishment, 2011. Dams and Reservoirs 25(2): 74-78, http://dx.doi.org/10.1680/jdare.16.00005.

Thomas HVH (2015) Briefing: An update on reservoir safety regulation in Scotland. Dams and Reservoirs 25(2): 51-53, http://dx.doi.org/10.1680/jdare.15.00021.

Tudor S (2015) The BDS Young Engineers' Forums role in succession planning. Dams and Reservoirs 25(2): 85-87, http://dx.doi.org/10.1680/jdare.15.00018.

Warren A (2015) Briefing: Legislative changes for supervising engineers - England. Dams and Reservoirs 25(2): 54-55, http://dx.doi.org/10.1680/jdare.15.00023. 